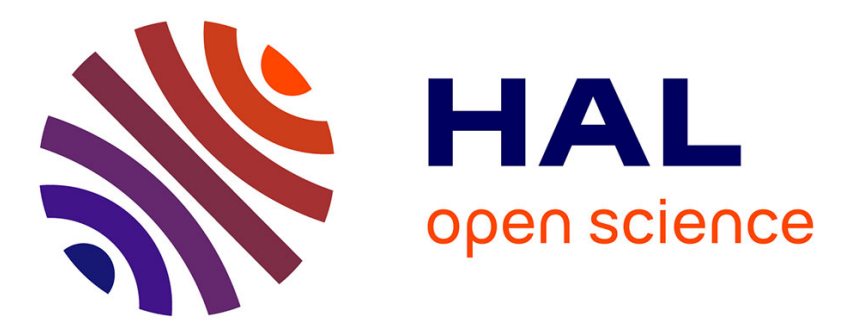

\title{
A simple synthesis of 2-keto-3-deoxy-D-erythro-hexonic acid isopropyl ester, a key sugar for the bacterial population living under metallic stress
}

Claire Grison, Brice-Loïc Renard, Claude Grison

\section{- To cite this version:}

Claire Grison, Brice-Loïc Renard, Claude Grison. A simple synthesis of 2-keto-3-deoxy-D-erythrohexonic acid isopropyl ester, a key sugar for the bacterial population living under metallic stress. Bioorganic Chemistry, 2014, 52, pp.50-55. 10.1016/j.bioorg.2013.11.006 . hal-03149058

\section{HAL Id: hal-03149058 https://hal.science/hal-03149058}

Submitted on 15 Mar 2021

HAL is a multi-disciplinary open access archive for the deposit and dissemination of scientific research documents, whether they are published or not. The documents may come from teaching and research institutions in France or abroad, or from public or private research centers.
L'archive ouverte pluridisciplinaire HAL, est destinée au dépôt et à la diffusion de documents scientifiques de niveau recherche, publiés ou non, émanant des établissements d'enseignement et de recherche français ou étrangers, des laboratoires publics ou privés. 


\title{
A simple synthesis of 2-keto-3-deoxy-D-erythro-hexonic acid isopropyl ester, a key sugar for the bacterial population living under metallic stress
}

\author{
Claire M. Grison ${ }^{\mathrm{a}, *}$, Brice-Loïc Renard ${ }^{\mathrm{b}}$, Claude Grison ${ }^{\mathrm{b}}$ \\ a ICMMO UMR 8182, Equipe Synthèse Organique E' Méthodologie, Université Paris Sud, Bât. 420, 15 rue Georges Clémenceau, 91405 Orsay cedex, France \\ ${ }^{\mathrm{b}}$ CEFE UMR 5175, Campus CNRS, 1919 route de Mende, 34293 Montpellier cedex 5, France
}

\begin{abstract}
A B S T R A C T
2-Keto-3-deoxy-D-erythro-hexonic acid (KDG) is the key intermediate metabolite of the Entner Doudoroff (ED) pathway. A simple, efficient and stereoselective synthesis of KDG isopropyl ester is described in five steps from 2,3-0-isopropylidene-D-threitol with an overall yield of 47\%. KDG isopropyl ester is studied as an attractive marker of a functional Entner Doudoroff pathway. KDG isopropyl ester is used to promote growth of ammonium producing bacterial strains, showing interesting features in the remediation of heavy-metal polluted soils.
\end{abstract}

2-Keto-3-deoxy-D-erythro-hexonic acid

isopropyl ester

Swern oxidation

Modified Darzens reaction

One-pot isomerization-reduction reaction

Entner Doudoroff pathway

Heavy-metal resistant rhizobia

\section{Introduction}

High ulosonic acids are well known to play an important structural role in the bacterial population. They are essential $\alpha$-ketoacids such as 2-keto-3-deoxy-D-manno-octonic acid (KDO), which is mostly found in the lipopolysaccharide (LPS) outer membrane of Gram negative bacteria and such as 2-keto-3-deoxy-D-arabinoheptonic acid (DAH), which plays a key role in the shikimic pathway of bacteria and plants. Therefore their chemical syntheses have often been studied to design new antibacterial agents for inhibiting their own biosynthetic pathway [1].

However, a little known ulosonic acid, 2-keto-3-deoxy-D-erythro-hexonic acid (or 2-keto-3-deoxy-D-gluconic acid, KDG), is the key intermediate metabolite in the Entner Doudoroff (ED) glycolytic pathway of certain microbial species, especially Gram negative bacterial species living in a stressful environment $[2,3]$. Two novel heavy-metal resistant bacterial species were found to be of particular interest, Rhizobium metallidurans and Mesorhizobium metallidurans [4,5]. They had been discovered growing on a highly polluted mining site of Les Avinières (Saint-Laurent-LeMinier, Gard, South of France) in symbiosis with the Zn hyperaccumulating legume Anthyllis vulneraria (Hyperaccumulating rate $=154 \mathrm{mg} \mathrm{kg}^{-1}$ of zinc) [6]. The novel strains had been found where the pollution is the highest, on the tailing basins ( $\mathrm{Zn}$ : $160 \mathrm{~g} \mathrm{~kg}^{-1}$, Pb: $84 \mathrm{~g} \mathrm{~kg}^{-1} \mathrm{Cd}: 1.3 \mathrm{~g} \mathrm{~kg}^{-1}$ of soil) and where the

\footnotetext{
* Corresponding author.

E-mail address: claire.grison@u-psud.fr (C.M. Grison).
}

vegetal and microbial diversity is the poorest. The ability to grow on a heavy-metal enriched soil devoid of carbon nutriment is a challenge. In such conditions, we assumed that their carbon metabolism is based on the ED pathway as the only glucose degradation way instead of the glycolytic pathway. This adaptation could be explained by the high selective pressure of a stressful environment $[3,7]$. KDG uptake would prove the presence and functionality of the ED pathway in bacterial strains.

Therefore a rapid and efficient synthesis of KDG was needed. However, few stereoselective chemical syntheses of KDG had been described in the literature. In 1991, Plantier-Royon et al. [8] reviewed the first chemical routes of KDG and chose to improve the most promising way. However KDG was obtained with an overall yield of 35\% in 6 steps from D-glucose, using a WittigHorner phosphonate reagent. During this period of years, Ramage et al. [9] also reported a complicated chemical route to KDG with a poor yield ( $<7 \%$ in 4 steps) from dioxalan- 4 -one, with a Wittig reagent. Therefore a new chemical synthesis to KDG is needed. We have previously reported a general synthesis of $\alpha$-ketoesters from carbonyl compounds, by using potassium alkyl dichloroacetates. Applied to a protected D-mannose, the method is convenient for the total synthesis of KDO [10]. This strategy is also very suitable to prepare the protected KDO under isopropyl carboxylic ester form, which is better for bacterial cell wall penetration [11]. We propose here an original but simple and enantiomerically pure synthesis of KDG isopropyl ester and microbiological assays of KDG isopropyl ester uptake, as a selective bacterial growth stimulator. 


\section{Experimental protocols}

All starting materials were commercially available researchgrade chemicals and used without further purification. Reactions were monitored by TLC (Merck - 5535 - Kieselgel 60-F 254 ), detection being carried out by UV, by iodine vapor or by spraying solution of $\mathrm{H}_{2} \mathrm{SO}_{4} 15 \%$ in ethanol followed by heating. NMR spectra were recorded on a Bruker DRX-300. Chemical shifts are expressed as parts per million downfield from the internal standard tetramethylsilane for ${ }^{1} \mathrm{H}$ and ${ }^{13} \mathrm{C}$. Multiplicities are indicated by $\mathrm{s}$ (singlet), d (doublet), dd (dedoubled doublet), t (triplet), q (quadruplet), $\mathrm{m}$ (multiplet), bs (broadened singlet); coupling constants are reported in Hertz $(\mathrm{Hz})$. IR spectra were recorded on a PerkinElmer Spectrum 100 FT-IR spectrometer, in ATR mode, and are given in $\mathrm{cm}^{-1}$. High-resolution mass spectrometry (HRMS) data were recorded using the electrospray ionization technique in positive mode (ESI+) with a tandem Q-TOF analyser (Bruker, 2009). Optical rotations were measured using a $10 \mathrm{~cm}$ quartz cell (Jasco, P-1010). Values for $[\propto]_{D}^{T}$ were obtained with the $\mathrm{D}$-line of sodium at the indicated temperature $T$, using solutions of concentration (c) in units of g. $100 \mathrm{~mL}^{-1}$. Column chromatography was performed on silica gel (MN Kieselgel 60, 0.063-0.2 mm/70-230 mesh, Macherey-Nagel). All primers were purchased from Invitrogen (Saint-Aubin, France).

\subsection{Chemical synthesis of 2-keto-3-deoxy-D-erythro-hexonic acid isopropyl ester $\mathbf{8}$}

\subsubsection{Synthesis of 4-0-tert-butyldimethylsilyl-2,3-O-isopropylidene- D-threitol 2}

To a suspension of $\mathrm{NaH}$ ( $60 \%$ in oil, $0.18 \mathrm{~g}, 6.63 \mathrm{mmol}, 1$ equiv) in THF $(10 \mathrm{~mL})$ was added, over 15 min under a stream of nitrogen at $5{ }^{\circ} \mathrm{C}$, a solution of $2,3-O$-isopropylidene-D-threitol $(1.30 \mathrm{~g}$, $6.63 \mathrm{mmol}, 1$ equiv) in THF $(12 \mathrm{~mL})$. The suspension was stirred for $45 \mathrm{~min}$ at $5{ }^{\circ} \mathrm{C}$. Then tert-butyldimethylsilyl chloride $(1 \mathrm{~g}$, $6.63 \mathrm{mmol}, 1$ equiv) in $2 \mathrm{~mL}$ of THF was added. After stirring for $16 \mathrm{~h}$, the reaction mixture was washed with $30 \mathrm{~mL}$ of saturated $\mathrm{NaHCO}_{3}$ and extracted three times with diethylether $(3 \times 20 \mathrm{~mL})$. The organic layer was dried over $\mathrm{MgSO}_{4}$, filtered and concentrated under reduced pressure. The residue was purified by silica chromatography (3:1 hexane/EtOAc) to give $1.75 \mathrm{~g}$ of compound 2 as yellow oil (98\% yield).

2: $\operatorname{Rf}(4: 1$ hexane/EtOAc $)=0.25 ;{ }^{1} \mathrm{H}$ RMN $\left(300 \mathrm{MHz}, \mathrm{CDCl}_{3}\right) \delta$ $0.10\left(\mathrm{~s}, 6 \mathrm{H}, \mathrm{Si}-\mathrm{CH}_{3}\right), 0.92(\mathrm{~s}, 9 \mathrm{H}, \mathrm{Si}-\mathrm{tBu}), 1.44$ (dd, $\left.6 \mathrm{H}, \mathrm{C}-\mathrm{CH}_{3}\right)$, 2.35 (bs, $1 \mathrm{H}, \mathrm{OH}), 3.71-4.03\left(\mathrm{~m}, 6 \mathrm{H}, 2 \mathrm{CH}_{2}-\mathrm{O}+2 \mathrm{CH}-\mathrm{O}\right) ;{ }^{13} \mathrm{C}$ NMR $\left(75 \mathrm{MHz}, \mathrm{CDCl}_{3}\right) \delta-5.3\left(\mathrm{Si}-\left(\mathrm{CH}_{3}\right)_{2}\right), 18.4\left(\mathrm{Si}-\mathrm{C}\left(\mathrm{CH}_{3}\right)_{3}\right), 25.7$

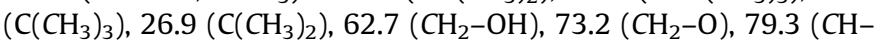

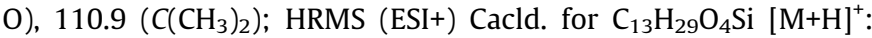
277.1835 , found 277.1829 .

\subsubsection{Synthesis of 4-O-tert-butyldimethylsilyl-2,3-O-isopropylidene- D-threose 3}

To a cooled $\left(-78{ }^{\circ} \mathrm{C}\right)$ solution of oxalyl chloride $(1.09 \mathrm{~g}$, $8.62 \mathrm{mmol}, 1.3$ equiv) in $\mathrm{CH}_{2} \mathrm{Cl}_{2}(23 \mathrm{~mL})$, under a stream of nitrogen, was added dropwise DMSO (1.35 g, $17.24 \mathrm{mmol}, 2.6$ equiv) in $\mathrm{CH}_{2} \mathrm{Cl}_{2}$ (4 mL). Then compound 2 ( $1.80 \mathrm{~g}, 6.63 \mathrm{mmol}, 1$ equiv) in $10 \mathrm{~mL}$ of $\mathrm{CH}_{2} \mathrm{Cl}_{2}$ was added dropwise. After stirring for $20 \mathrm{~min}$, triethylamine ( $3.35 \mathrm{~g}, 33.15 \mathrm{mmol}, 5$ equiv) was added and the reaction was allowed to warm to $20^{\circ} \mathrm{C}$ over a period of $1 \mathrm{~h}$. The heterogeneous mixture was extracted with water, diluted in $1: 1$ hexane/ether) and extracted three more times with water $(3 \times 25 \mathrm{~mL})$. Then the combined aqueous fractions were extracted with (1:1 hexane/ether) and the combined organic layers were dried over $\mathrm{Na}_{2} \mathrm{SO}_{4}$, filtered and concentrated under reduced pressure. After coevaporation with toluene, the crude aldehyde 3 (Rf
$(5: 1$ hexane/EtOAc $)=0.5)$ was used immediately in the synthesis of compound $\mathbf{5}$.

\subsubsection{Synthesis of isopropyl dichloroacetate 4}

To $150 \mathrm{~mL}$ of anhydrous isopropanol $(117.90 \mathrm{~g}, 1.961 \mathrm{~mol}$, 13 equiv) were added dichloroacetic acid (19.35 g, $150 \mathrm{mmol}$, 1 equiv) and $2 \mathrm{~mL}$ of sulfuric acid ( $36 \mathrm{~N})$. The solution was stirred for $26 \mathrm{~h}$ at $100{ }^{\circ} \mathrm{C}$. Isopropanol was then evaporated under reduced pressure. The remaining yellow oil was dissolved in $60 \mathrm{~mL}$ of diethylether, washed with an aqueous solution of $\mathrm{NaHCO}_{3} 8 \%$ until $\mathrm{pH}=8$ and extracted three times with diethylether. The organic layer was dried over $\mathrm{MgSO}_{4}$, filtered and concentrated under reduced pressure to give $24 \mathrm{~g}$ of compound 4 as yellow oil (96\% yield). The analytical data were consistent with literature [10].

\subsubsection{Synthesis of 2,3-anhydro-2-C-chloro-6-0-[(1,1-} dimethylethyl)dimethylsilyl]-4,5-O-isopropylidene-D-erythro-hexonic acid 1-methylethyl ester $\mathbf{5}$

A suspension of solid potassium $(0.52 \mathrm{~g}, 13.2 \mathrm{mmol}, 2$ equiv) in $41 \mathrm{~mL}$ of isopropanol under nitrogen was stirred until complete dissolution of potassium. After addition of $8 \mathrm{~mL}$ of diethylether, the solution was cooled to $0{ }^{\circ} \mathrm{C}$ and a mixture of $3(6.63 \mathrm{mmol}$, 1 equiv) and isopropyl dichloroacetate $4(2.26 \mathrm{~g}, 13.2 \mathrm{mmol}$, 2 equiv) in $32 \mathrm{~mL}$ of diethylether, was added dropwise for $30 \mathrm{~min}$. The mixture was stirred for $2 \mathrm{~h}$, neutralized by addition of saturated $\mathrm{HCl}$ solution in diethylether and centrifuged (1000 rpm, $15 \mathrm{~min}$ ). The supernatant was taken off, concentrated and purified by silica chromatography ( $5: 1$ hexane/EtOAc) to give 2,21 $\mathrm{g}$ of compound $\mathbf{5}$ as brownish oil (71\% yield).

5a (60\%): Rf $\left(5: 1\right.$ hexane/EtOAc) $=0.5 ;{ }^{1} \mathrm{H}$ RMN $(300 \mathrm{MHz}$, $\left.\mathrm{CDCl}_{3}\right) \delta 0.09\left(\mathrm{~s}, 6 \mathrm{H}, \mathrm{Si}-\mathrm{H}_{3}\right), 0.91(\mathrm{~s}, 9 \mathrm{H}, \mathrm{Si}-\mathrm{tBu}), 1.43-1.44(\mathrm{~s}, 6$ $\left.\mathrm{H}, \mathrm{C}-\mathrm{CH}_{3}\right), 1.46-1.48\left(\mathrm{~m}, 6 \mathrm{H}, \mathrm{CH}-\mathrm{CH}_{3}\right), 3.50-3.52(\mathrm{~d}, 1 \mathrm{H}, \mathrm{CH}-\mathrm{O})$, 3.80-3.90 (2dd, $2 \mathrm{H}, \mathrm{CH}_{2}$-OTBDMS), 4.05-4.30 (m, $2 \mathrm{H}, 2 \mathrm{CH}-\mathrm{O}$ ), 5.09-5.18 (h, $1 \mathrm{H}, \mathrm{O}-\mathrm{CH}-) ;{ }^{13} \mathrm{C}$ NMR $\left(75 \mathrm{MHz}, \mathrm{CDCl}_{3}\right) \delta-5.3(\mathrm{Si}-$

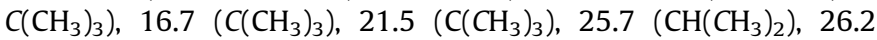
$\left(\mathrm{C}\left(\mathrm{CH}_{3}\right)_{2}\right), 63.2(\mathrm{CH}-\mathrm{O}(\mathrm{CCl})), 65.2\left(\mathrm{CH}_{2}-\mathrm{O}\right), 65.9(\mathrm{Cl}-\mathrm{C}-\mathrm{O}), 66.5$ $(\mathrm{CH}-\mathrm{O}), 67.8(\mathrm{CH}-\mathrm{O}), 73.4\left(\mathrm{CH}\left(\mathrm{CH}_{3}\right)_{2}\right), 111.5\left(\mathrm{C}_{\left.\left(\mathrm{CH}_{3}\right)_{2}\right),}, 163.7\right.$ $(\mathrm{C}=\mathrm{O})$.

5b (40\%): Rf (5:1 hexane/EtOAc) $=0.5 ;{ }^{1} \mathrm{H}$ RMN $(300 \mathrm{MHz}$, $\left.\mathrm{CDCl}_{3}\right) \delta 0.09\left(\mathrm{~s}, 6 \mathrm{H}, \mathrm{Si}-\mathrm{CH}_{3}\right), 0.91(\mathrm{~s}, 9 \mathrm{H}, \mathrm{Si}-\mathrm{tBu}), 1.31-1.32(\mathrm{~s}, 6$ $\left.\mathrm{H}, \mathrm{C}-\mathrm{CH}_{3}\right), 1.46-1.48\left(\mathrm{~m}, 6 \mathrm{H}, \mathrm{CH}-\mathrm{CH}_{3}\right), 3.51(\mathrm{~d}, 1 \mathrm{H}, \mathrm{CH}-\mathrm{O})$, 3.60-3.88 (2dd, $2 \mathrm{H}, \mathrm{CH}_{2}$-OTBDMS), 4.05-4.30 (m, $2 \mathrm{H}, 2 \mathrm{CH}-\mathrm{O}$ ), 5.09-5.18 (h, $1 \mathrm{H}, \mathrm{O}-\mathrm{CH}-)$; ${ }^{13} \mathrm{C}$ NMR $\left(75 \mathrm{MHz}, \mathrm{CDCl}_{3}\right) \delta-5.3(\mathrm{Si}-$ $\left.\mathrm{C}\left(\mathrm{CH}_{3}\right)_{3}\right), 16.7\left(\mathrm{C}\left(\mathrm{CH}_{3}\right)_{3}\right), 21.5\left(\mathrm{C}\left(\mathrm{CH}_{3}\right)_{3}\right), 25.7\left(\mathrm{CH}\left(\mathrm{CH}_{3}\right)_{2}\right), 26.2$ $\left(\mathrm{C}\left(\mathrm{CH}_{3}\right)_{2}\right), 62.4(\mathrm{CH}-\mathrm{O}(\mathrm{CCl})), 64.6\left(\mathrm{CH}_{2}-\mathrm{O}\right), 65.9(\mathrm{Cl}-\mathrm{C}-\mathrm{O}), 66.5$ $(\mathrm{CH}-\mathrm{O}), 67.8(\mathrm{CH}-\mathrm{O}), 73.4\left(\mathrm{CH}\left(\mathrm{CH}_{3}\right)_{2}\right), 111.2\left(\mathrm{C}\left(\mathrm{CH}_{3}\right)_{2}\right), 163.7$ $(\mathrm{C}=\mathrm{O})$.

HRMS (ESI+) Cacld. for $\mathrm{C}_{18} \mathrm{H}_{33} \mathrm{ClNaO}_{6} \mathrm{Si}[\mathrm{M}+\mathrm{Na}]^{+}$: 431.1633, found 431.1635

\subsubsection{One-pot sequential synthesis of 3-deoxy 6-O-[(1,1-} dimethylethyl)dimethylsilyl]-4,5-0-(1-methylethylylidene)-D-erythrohexulosonic acid 1-methylethyl ester 7

To a suspension of solid magnesium $(0.08 \mathrm{~g}, 3.25 \mathrm{mmol}$, 1.3 equiv) in $22 \mathrm{~mL}$ of diethylether was added grinded iodine ( $0.83 \mathrm{~g}, 3.25 \mathrm{mmol}, 1.3$ equiv). After stirring for $3 \mathrm{~h}$ at $35^{\circ} \mathrm{C}$ in the dark, compound 5 ( $1 \mathrm{~g}, 2.50 \mathrm{mmol}, 1$ equiv) in $14 \mathrm{~mL}$ of diethylether was added dropwise. The solution was refluxed for $2 \mathrm{~h}$ to give $\mathbf{6 a}$ and $\mathbf{6 b}$. A fraction of the reaction mixture was isolated to characterize $\mathbf{6 a}$ and $\mathbf{6 b}$. $6 \mathbf{a}$ and $\mathbf{6 b}$ were not enough stable to obtain ${ }^{13} \mathrm{C}$ NMR data.

6a, 6b: $\operatorname{Rf}(5: 1$ hexane/EtOAc $)=0.57 ;{ }^{1} \mathrm{H}$ RMN $\left(300 \mathrm{MHz}, \mathrm{CDCl}_{3}\right)$ $\delta 0.08\left(\mathrm{~s}, 12 \mathrm{H}, \mathrm{Si}-\mathrm{CH}_{3}\right), 0.91(\mathrm{~s}, 18 \mathrm{H}, \mathrm{Si}-\mathrm{tBu}), 1.34-1.40(\mathrm{~m}, 24 \mathrm{H}$, C- $\mathrm{CH}_{3}, \mathrm{CH}-\mathrm{CH}_{3}$ ), 3.67-3.72 (2dd, $2 \mathrm{H}, \mathrm{CH}_{2}-\mathrm{OTBDMS}$ ), 3.78-3.83 (m, $2 \mathrm{H}, \mathrm{CH}-\mathrm{O}$ ), 3.84-3.89 (2dd, $2 \mathrm{H}, \mathrm{CH}_{2}-\mathrm{OTBDMS}$ ), 4.05-4.30 (d, $1 \mathrm{H}, \mathrm{CH}-\mathrm{O}), 4.17-4.25$ (d, $1 \mathrm{H}, \mathrm{CH}-\mathrm{O}), 4.35-4.42(\mathrm{~d}, 2 \mathrm{H}$, 
$\mathrm{CH}_{2}-\mathrm{I}$ ), 5.1-5.2 (h, $2 \mathrm{H}, \mathrm{O}-\mathrm{CH}-$ ); HRMS (ESI+) Cacld. for $\mathrm{C}_{18} \mathrm{H}_{34} \mathrm{IO}_{6} \mathrm{Si}$ $[\mathrm{M}+\mathrm{H}]^{+}:$501.1169, found 501.1171.

After cooling, a freshly prepared aqueous solution of $\mathrm{Na}_{2} \mathrm{~S}_{2} \mathrm{O}_{5} 8 \%$ was added to $\mathbf{6 a} / \mathbf{6 b}$ and the resulting mixture was stirred for $30 \mathrm{~min}$ at $20^{\circ} \mathrm{C}$, extracted with diethylether. The organic layer was dried over $\mathrm{Na}_{2} \mathrm{SO}_{4}$, filtered and concentrated under reduced pressure to give $0.59 \mathrm{~g}$ of compound 7 (64\% yield).

2.1.6. One-pot synthesis of 3-deoxy-6-O-[(1,1-

dimethylethyl)dimethylsilyl]-4,5-0-(1-methylethylylidene)-D-erythrohexulosonic acid 1-methylethyl ester 7

To a suspension of solid magnesium $(0.13 \mathrm{~g}, 5.25 \mathrm{mmol}$, 2.1 equiv) in $5 \mathrm{~mL}$ of diethylether was added grinded iodine ( $0.63 \mathrm{~g}, 2.5 \mathrm{mmol}, 1$ equiv). After stirring for $1 \mathrm{~h}$ at $35^{\circ} \mathrm{C}$ in the dark, compound $\mathbf{5}$ ( $1 \mathrm{~g}, 2.50 \mathrm{mmol}, 1$ equiv) in $8 \mathrm{~mL}$ of diethylether was added dropwise at $20^{\circ} \mathrm{C}$. The solution was refluxed for $2 \mathrm{~h}$ and stirred for $15 \mathrm{~h}$ at $20^{\circ} \mathrm{C}$, then extracted with diethylether. The organic layer was filtered on silica before, dried over $\mathrm{Na}_{2} \mathrm{SO}_{4}$ and concentrated under reduced pressure. $0.72 \mathrm{~g}$ of compound 7 was obtained as pale yellow oil ( $78 \%$ yield).

7: $\mathrm{Rf}(5: 1$ hexane/EtOAc $)=0.61 ;{ }^{1} \mathrm{H}$ RMN $\left(300 \mathrm{MHz}, \mathrm{CDCl}_{3}\right) \delta$ $0.12\left(\mathrm{~s}, 6 \mathrm{H}, \mathrm{Si}-\mathrm{CH}_{3}\right), 0.92(\mathrm{~s}, 9 \mathrm{H}, \mathrm{Si}-t \mathrm{Bu}), 1.23-1.40(\mathrm{~m}, 12 \mathrm{H}$, $\left.\mathrm{CH}-\mathrm{CH}_{3}+\mathrm{C}-\mathrm{CH}_{3}\right), 2.70-2.80\left(\mathrm{~d}, 1 \mathrm{H}, \mathrm{CH}_{2}\right), 3.67-3.91(2 \mathrm{dd}, 2 \mathrm{H}$, $\mathrm{CH}_{2}$-OTBDMS), 4.19-4.44 (m, $\left.2 \mathrm{H}, 2 \mathrm{CH}-\mathrm{O}\right), 5.23-5.40(\mathrm{~h}, 1 \mathrm{H}$, $\mathrm{O}-\mathrm{CH}-) ;{ }^{13} \mathrm{C}$ NMR $\left(75 \mathrm{MHz}, \mathrm{CDCl}_{3}\right) \delta-5.7\left(\mathrm{Si}-\left(\mathrm{CH}_{3}\right)_{2}\right), 15.3$

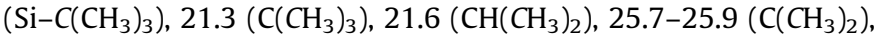
$29.7\left(\mathrm{CH}_{2}\right), 64.6\left(\mathrm{CH}_{2}-\mathrm{O}\right), 65.8(\mathrm{CH}-\mathrm{O}), 71.9\left(\mathrm{CH}\left(\mathrm{CH}_{3}\right)_{2}\right), 109.6$ $\left(\mathrm{C}\left(\mathrm{CH}_{3}\right)_{2}\right), 164(\mathrm{C}=\mathrm{O}), 191.9(\mathrm{C}=\mathrm{O})$; HRMS (ESI+) Cacld. for $\mathrm{C}_{18} \mathrm{H}_{34}$ $\mathrm{NaO}_{6} \mathrm{Si}[\mathrm{M}+\mathrm{Na}]^{+}:$397.2022, found 397.2017; $[\propto]_{\mathrm{D}}^{29}-19.3^{\circ}$ (c 1.0, $\left.\mathrm{CHCl}_{3}\right)$.

2.1.7. Synthesis of 3-deoxy-D-erythro-hexulosonic acid 1-methylethyl ester 8 and 3-deoxy-3,4,5,6-0-tetrasilyl-D-erythro-hexulosonic acid 1-methylethyl ester $\mathbf{9}$

$100 \mathrm{~mL}$ of an aqueous solution of formic acid 50\% was added to compound $7(0.20 \mathrm{~g}, 0.53 \mathrm{mmol})$, the solution was stirred for $24 \mathrm{~h}$ at $20^{\circ} \mathrm{C}$ and concentrated under reduced pressure to give $0.1 \mathrm{~g}$ of $\mathbf{8}$ ( $87 \%$ yield). After persilylation $0.20 \mathrm{~g}$ of compound $\mathbf{9}$ were obtained as yellow oil ( $100 \%$ yield).

9: $\operatorname{Rf}(5: 1$ hexane/EtOAc $)=0.25 ;{ }^{1} \mathrm{H}$ RMN $\left(300 \mathrm{MHz}, \mathrm{CDCl}_{3}\right) \delta 0-$ $0.39\left(\mathrm{~m}, 27 \mathrm{H}, \mathrm{Si}-\left(\mathrm{CH}_{3}\right)_{3}\right), 1.28-1.37\left(\mathrm{~m}, 6 \mathrm{H}, \mathrm{CH}-\mathrm{CH}_{3}\right), 2.84-2.92$ (dd, $1 \mathrm{H}, \mathrm{CH}_{2}$ ), 3.09-3.16 (dd, $2 \mathrm{H}, \mathrm{CH}_{2}$ ), 3.53-3.90 (m, $2 \mathrm{H}, \mathrm{CH}_{2}-$ OTBDMS), $4.16-4.45$ (m, $2 \mathrm{H}, 2 \mathrm{CH}-\mathrm{O}), 5.04-5.20$ (h, $1 \mathrm{H}, \mathrm{O}-\mathrm{CH}-$ ); ${ }^{13} \mathrm{C} \mathrm{NMR}\left(75 \mathrm{MHz}, \mathrm{CDCl}_{3}\right) \delta-4.9\left(\mathrm{Si}-\left(\mathrm{CH}_{3}\right)_{3}\right), 14.9\left(\mathrm{CH}_{3}\right), 30.5$ $\left(\mathrm{CH}_{2}\right), 66.2\left(\mathrm{CH}_{2}-\mathrm{O}\right), 67.1(\mathrm{CH}-\mathrm{O}), 74.4\left(\mathrm{CH}_{\left.\left(\mathrm{CH}_{3}\right)_{2}\right),} 165(\mathrm{C}=\mathrm{O})\right.$, $192.1(\mathrm{C}=\mathrm{O})$; IR $\left(\mathrm{cm}^{-1}\right) 1739$ ( $\mathrm{C}=\mathrm{O}$ ester $), 1711$ ( $\mathrm{C}=\mathrm{O}$ ketone); HRMS (ESI+) Cacld. for $\mathrm{C}_{8} \mathrm{H}_{40} \mathrm{NaO}_{6} \mathrm{Si}_{3}[\mathrm{M}+\mathrm{Na}]^{+}$: 459.2030, found 459.2041

\subsection{Microbiological growth test}

\subsubsection{Total DNA isolation from Anthyllis vulneraria rhizosphere}

Soil samples were collected on the mining site of Saint-LaurentLe-Minier. $1 \mathrm{~kg}$ of soil samples were extracted from the rhizosphere of 15 plants of $A$. vulneraria. They were stored at $4{ }^{\circ} \mathrm{C}$ until analysis in the laboratory within 4 days. Total DNA was isolated by a Powersoil DNA isolation kit as recommended by the producer (MOBIO, Carlsbad, Canada). DNA concentration was checked by Nanodrop measurement. Each combined DNA isolate was precipitated by sodium acetate $(12.5 \%)$ and isopropanol to be concentrated.

\subsubsection{S rDNA library from Anthyllis vulneraria rhizosphere}

A region of approximately $1500 \mathrm{bp}$ of $16 \mathrm{~S}$ rDNA genes was amplified using the primers $27 \mathrm{f}$ ( $5^{\prime}$-AGAGTTTGATCMTGGCT CAG-3') and 1492r (5'-ACCTTGTTACGACTT-3') and cloned before sequencing. [12] The sequenced full-legnth 16S rDNA genes were well suited for phylogenetic analysis. The analyses were based on around 800 nucleotides. [13] The similarity searches for sequences were carried out by the BLASTN program of the National Center of Biotechnology Information, MD, USA.

The 16S rDNA gene library was kept in $20 \%$ glycerol $(\mathrm{v} / \mathrm{v})$ at $-80^{\circ} \mathrm{C}$.

\subsubsection{KDG isopropyl ester-enriched medium}

Growth test was performed on glucose minimal medium $\left(\mathrm{Na}_{2} \mathrm{HPO}_{4}(120 \mathrm{mM}), \mathrm{KH}_{2} \mathrm{PO}_{4}(55 \mathrm{mM}), \mathrm{NaCl}(20 \mathrm{mM}), \mathrm{NH}_{4} \mathrm{Cl}\right.$ (45 mM), $\mathrm{MgSO}_{4}(20 \mathrm{mM}), \mathrm{CaCl}_{2}(2 \mathrm{mM})$ and glucose $\left.(20 \mathrm{mM})\right)$ and KDG isopropyl ester minimal medium $\left(\mathrm{Na}_{2} \mathrm{HPO}_{4}(120 \mathrm{mM})\right.$,

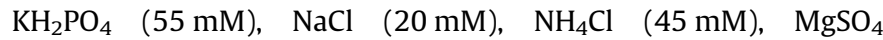
(20 mM), $\mathrm{CaCl}_{2}(2 \mathrm{mM})$ and $\left.\mathrm{KDG}(20 \mathrm{mM})\right)$.

\section{Results and discussion}

\subsection{Synthesis of KDG isopropyl ester}

According to our previous chemical syntheses of superior ulosonic acid analogs (KDO, DAH) [11] we designed a rapid strategy based on the use of alkyldihalogenoacetate in chain extension of an aldose with a $\alpha$-ketoester unit. It constituted a $[n+2]$ methodology which led to an enantiopure ulosonic acid. Since configuration of KDG is D-erythro, protected D-erythrose would be the saccharide to use. However no protected D-erythrose precursor is commercially available because of its instability. Evans et al. [14] had described an access to 4-O-tert-butyldimethylsilyl-2,3-O-isopropylidene-D-erythrose. But this synthesis was tricky and hard to reproduce.

Therefore D-threo compound was chosen as the carbohydrate precursor. Thus KDG synthesis was based on a key step of epimerization of the $\mathrm{D}$-threose $\beta$-position. The epimerization was induced by a Swern oxidation of protected D-threitol and a diastereoselective Darzens type condensation [15].

A potassic enolate anion derived from isopropyl dichloroacetate was a synthetic equivalent of ("- $\left.\mathrm{C}(\mathrm{O}) \mathrm{COO}^{-\prime}\right)$ synthon. It was added on a judiciously protected D-threose. This last was prepared from commercial 2,3-O-isopropylidene-D-threitol 1 (Scheme 1).

According to Condon et al. [16], it was selectively monosilylated into 2 with tert-butyldimethylsilyl chloride and one equivalent of strong base $\mathrm{NaH}$. Swern oxidation was performed in basic conditions which partially epimerized the $\beta$-position of $\mathbf{2}$ as expected [17]. It led to a mixture of protected D-erythrose and D-threose $\mathbf{3 a} / \mathbf{3 b}$, which were not isolated and directly engaged into the following step. Darzens modified reaction was also carried out in basic conditions on the crude aldehydes $\mathbf{3 a} / \mathbf{3 b}$, with the potassic anion of isopropyl dichloroacetate $\mathbf{4}$ in alcohol-ether solvent. The proportion of solvents (isopropanol/ether: 50/50) played an important role. Isopropanol was used as a protic solvent to stabilize the alcoolate formed during the early stage of the reaction. Purification of the crude product by chromatography over silica gel afforded a diastereoisomeric mixture of $\alpha$-chloroglycidic esters $\mathbf{5}$ in high yield.

It is noteworthy that Darzens reaction leads to the formation of two new stereogenic centers, C- 2 and C-3 positions. Since Darzens modified reaction had been conducted on two aldehyde epimers, eight diastereoisomers could be obtained. But we have previously shown that the carboxylic ester group was only in trans position of the carbon chain $[10,11,15]$, so only four diastereoisomers could be obtained.

In some cases, we have shown that Darzens modified reaction proceeded in total epimerization in carbohydrate series on C-4 positions. For example, the sequence Swern oxidation/Darzens 


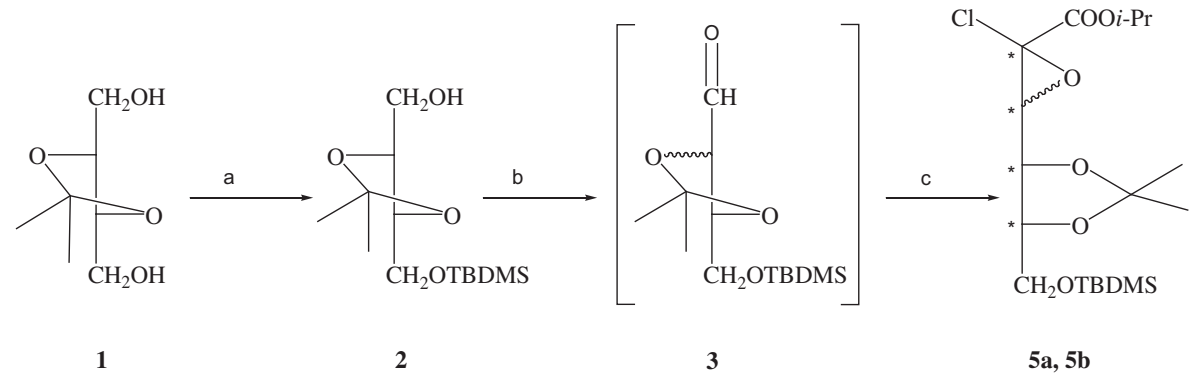

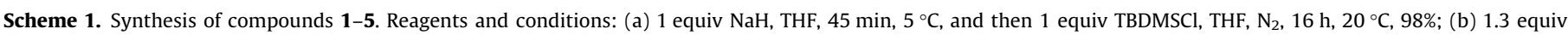

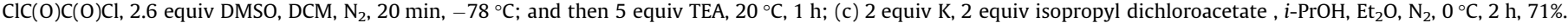

modified reaction of protected D-mannose led to chloro epoxy ester derived from D-glucose [11]. We observed the same tendency with D-threose. Only two epimers were observed in ${ }^{1} \mathrm{H}$ NMR and ${ }^{13} \mathrm{C}$ NMR. So we could conclude that the epimerization into C-4 position was complete. The ratio of the two epimers $\mathbf{5 a} \mathbf{a} \mathbf{5 b}$ was established by the integration of H-6 of (60/40).

Previously, we have described the mild opening of $\alpha$-halogenoepoxy ester with Lewis acids to introduce directly a $\beta$-halogeno- $\alpha$ keto ester moiety on a carbonyl compound [15]. In the present case the application of this strategy to the suitable protected $\alpha$-chloroglycidic esters $\mathbf{5 a} \mathbf{a} \mathbf{5 b}$ should give the required $\beta$-iodo- $\alpha$-ketoester precursor $\mathbf{6}$. 5a/5b were treated with one equivalent of magnesium iodide in ether. It led to the rearrangement of the chloroepoxy ring into a mixture of the $\beta$-iodo- $\alpha$-ketoester diastereoisomers $\mathbf{6 a} / \mathbf{6 b}$ with an excellent yield (Scheme 2).

Subsequent reduction of $\mathbf{6 a / 6 b}$ gave the protected target molecule 7. Two approaches were investigated.

The first was the reduction of $\mathrm{C}-\mathrm{I}$ bond with an aqueous solution of $\mathrm{NaHSO}_{3}$ which yielded to the enol form of 7 .

A proper one-pot strategy of isomerization-reduction was also performed. It was based on the preparation of the enolate derived from an $\alpha$-ketoester from the reaction between the $\beta$-iodo- $\alpha$-ketoester precursors 6 and active magnesium (like to prepare the corresponding Grignard reagent)(Scheme 1) [18]. Magnesium was intentionally used in a ratio $\mathrm{Mg} / \mathrm{I}_{2}=2 / 1$ in the preparation of $\mathrm{MgI}_{2}$ to completely transform in situ the $\alpha$-chloroglycidic esters into iodomagnesium enolates $\mathbf{6}^{\prime}$ (Scheme 2 ). These enolates were hydrolyzed to give the enol form of $\mathbf{7}$.

The $\alpha$-enolester was observed because of the presence of a stabilizing intramolecular hydrogen bond between the alcohol from the enol function and the carbonyl from the carboxylic acid function. After a simple filtration on silica, it gave the $\alpha$-ketoester $\mathbf{7}$.

Despite the fragility of erythro derivatives, we found that the two methodologies of isomerization-reduction of $\mathbf{5}$ were very convenient and directly afforded the ketoester $\mathbf{7}$ in good yields.

A final acid hydrolysis by formic acid (50\% in water) was achieved for simultaneous removal of the isopropylidene and $O$-silyl group to give the compound $\mathbf{8}$. The isopropyl ester was kept to allow protected KDG 8 penetration through Gram negative cellwall $[19,20]$. The product $\mathbf{8}$ was persilylated into $\mathbf{9}$ to allow a better characterization by NMR, IR and GCMS. The silylation involved a green method based on the use of hexamethyldisilazane catalyzed by $\mathrm{Zn}$ hyperaccumulating plants as we have previously described [21]. In these conditions, 8 directly afforded the target molecule entirely silylated $\mathbf{9}$ (quantitative yield). In ${ }^{1} \mathrm{H}$ NMR, each hydrogen of $\mathrm{CH}_{2}$ group in $\mathbf{9}$ appeared as a doublet of doublet at 2.8 and $3.1 \mathrm{ppm}$. These data were typical of pyruvic ester moiety. The IR data confirmed the assignment. We observed notably the presence

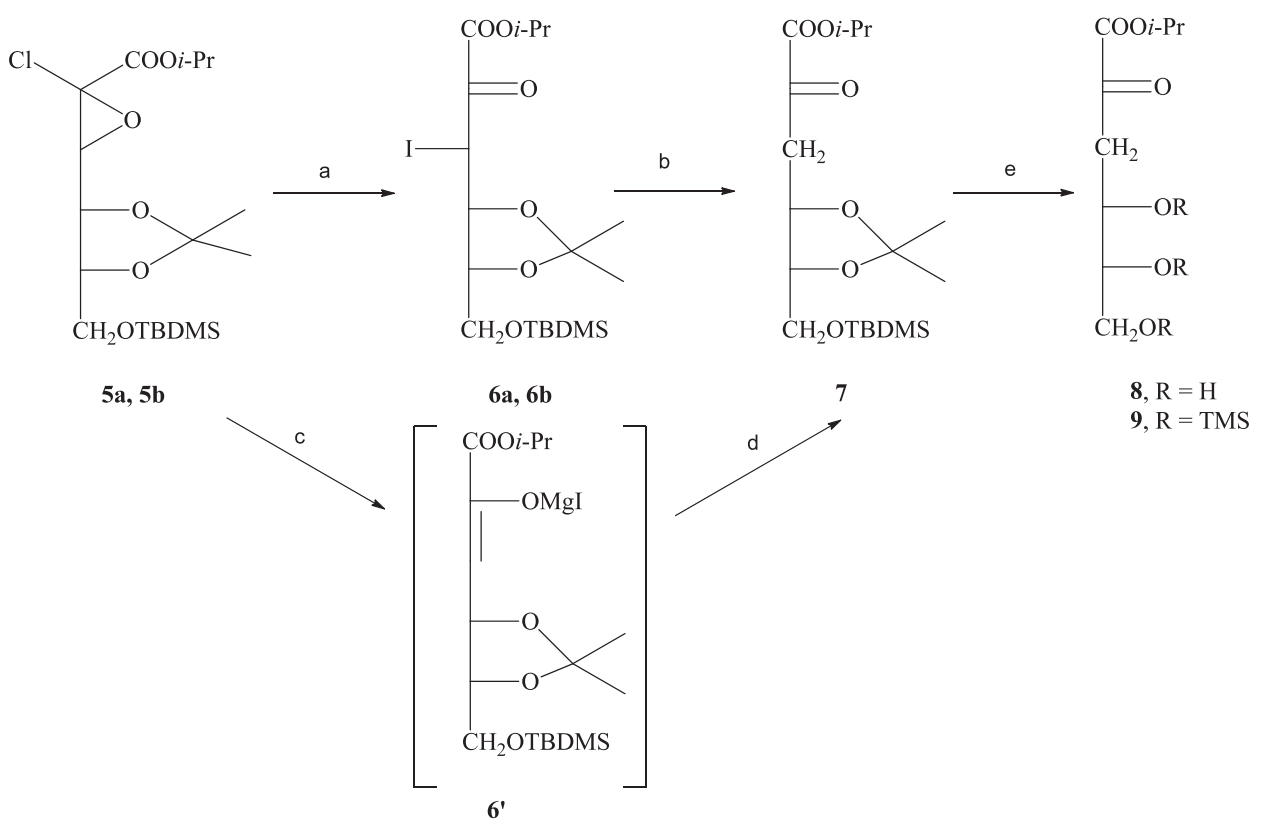

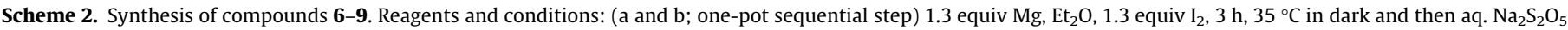
$8 \%, 30 \mathrm{~min}, 20^{\circ} \mathrm{C}, 64 \%$ (c and d; one-pot step) 2.1 equiv $\mathrm{Mg}, \mathrm{Et}_{2} \mathrm{O}, 1$ equiv $\mathrm{I}_{2}, 1 \mathrm{~h}$ at $35^{\circ} \mathrm{C}$ in dark then $15 \mathrm{~h}$ at $20{ }^{\circ} \mathrm{C}, 78 \%$; (e) Aq. Formic acid $50 \%, 20{ }^{\circ} \mathrm{C}, 24 \mathrm{~h}, 87 \%$. 


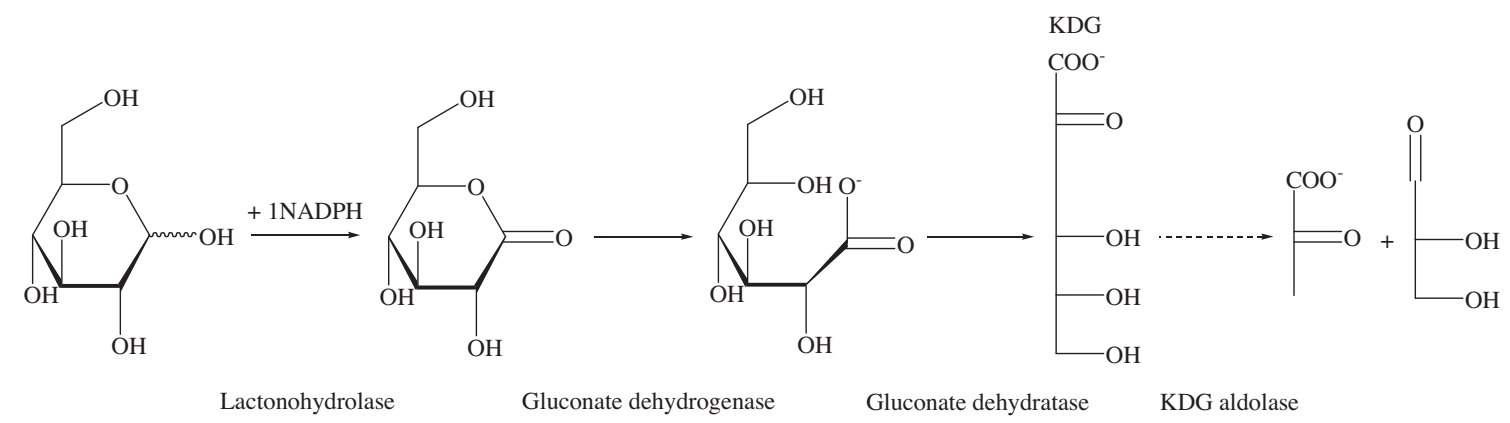

Scheme 3. Non-phosphorylative Entner Doudoroff pathway.

of absorption bands at $1711 \mathrm{~cm}^{-1}$ for the $\mathrm{C}=\mathrm{O}$ bond of the ketone and $1739 \mathrm{~cm}^{-1}$ for the $\mathrm{C}=\mathrm{O}$ bond of the ester group, characteristic of the $\alpha$-ketocarboxylic ester.

\subsection{Microbiological tests of competitive growth}

KDG is the key intermediate metabolite of the ED pathway (Scheme 3). It is specific of this pathway and cannot be metabolized in another glycolytic pathway. It can be used as a marker of a functional ED pathway. Moreover, it might be used to stimulate specifically the growth of bacteria using the ED pathway. It would avoid competition to glucose.

In Saint-Laurent-Le-Minier, carbon source availability is quite low because of the high pollution and thus the low abundance of vegetation. A vast program of revegetation started with the hyperaccumulating plant and $R$. metallidurans host, A. vulneraria [22]. $R$. metallidurans living in symbiosis with the legume, promotes its growth by producing ammonium from atmospheric $\mathrm{N}_{2}$ fixation. Thereby stimulating selectively $R$. metallidurans growth among the total microbial population from Saint-Laurent-Le-Minier soil would stimulate $A$. vulneraria growth.

The microbial diversity of the polluted soil from Saint-LaurentLe-Minier had been investigated. A cultur-independent approach was chosen to create a $16 \mathrm{~S}$ rDNA library of 303 clones from the rhizosphere of $A$. vulneraria. According to searches similarity on BLASTN, 93\% of the clones are novel species. We chose their most closely cultured related strains (>95\% of similarity) to compare their growth with $R$. metallidurans on a KDG minimal medium.

Table 1

Growth comparison of most closely related strains of the library clones on glucose minimal medium and KDG minimal medium; +, growth; -, no growth; w, weak growth; ND, not determined; "Rhizobium metallidurans had been found in the soil in addition to the nodules of Anthyllis vulneraria; ${ }^{* *}$ Staphylococcus aureus was not present in the soil, it represented a negative control.

\begin{tabular}{llll}
\hline Sugar-enriched medium & $\begin{array}{l}\text { Number of } \\
\text { related clones }\end{array}$ & Glucose & $\begin{array}{l}\text { KDG } \\
\text { isopropyl ester }\end{array}$ \\
\hline Rhizobium metallidurans* & 2 & + & + \\
Staphylococcus aureus** & 0 & + & - \\
Arenimonas metalli & 1 & + & - \\
Azotobacter beijerinckii & 1 & + & + \\
Bradyrhizobium canariense & 3 & + & w \\
Brevibacillus brevis & 4 & + & - \\
Burkholderia sp. & 2 & + & + \\
Gluconacetobacter diazotrophicus & 1 & + & - \\
Limnobacter litoralis & 3 & - & - \\
Nitrospira sp. & 7 & + & - \\
Nitrosospira multiformis & 6 & + & - \\
Rubrobacteridae & 1 & $\mathrm{ND}$ & $\mathrm{ND}$ \\
Segetibacter koreensis & 3 & + & - \\
Sphingomonas elodea & 2 & + & + \\
Thermobaculum terrenum & 1 & + & - \\
Xanthomonas campestris & 2 & + & - \\
\hline
\end{tabular}

Bacterial population evolution could not be measured in solution, because most of the strains produce extracellular polysaccharides whilst forming aggregates, which is characteristic of biofilm formation. The comparison of growth was carried out on solid media with glucose as the sole source of carbon, for a positive growth control, and with KDG as the sole source of carbon, highlighting the functionality of the ED pathway (Table 1).

$75 \%$ of the most closely related strains were not able to grow on KDG minimal medium. Therefore KDG promoted only $25 \%$ of the most closely related strains within the $R$. metallidurans target by avoiding the substrate uptake competition. We assumed that they were able to uptake KDG isopropyl ester and hydrolyze it before metabolizing it within the cell, through the ED pathway; as we had previously shown for an analog of KDO [11].

It was noticed that the growth-promoted strains by KDG are all capable of producing ammonium by fixing atmospheric $\mathrm{N}_{2}$, which should enrich the polluted soil and promote the growth of hyperaccumulating plants.

\section{Conclusion}

We described here an enantiomerically pure and original synthesis of 3-deoxy-D-erythro-hexulosonic acid isopropyl ester with good yield. The chiral configuration of the final product was controlled through a Swern oxidation followed by a diastereoselective Darzens type condensation leading to the epimerization of the KDG $\beta$-position. The presented results constituted a novel efficient synthesis of partially or completely protected KDG. Partially protected KDG uptake was tested on the total microbial diversity from SaintLaurent-Le-Minier soil by growth assays. Only $25 \%$ of the total microbial population growth was promoted by 3-deoxy-D-erythro-hexulosonic acid isopropyl ester. These strains, which are all capable of producing ammonium, constitute huge benefits to agriculture, especially in a nutrient-poor soil. This microbial biotechnology promoted by KDG isopropyl ester feeding constitutes a promising green process to restore polluted soil by stimulating a revegetation project.

\section{Acknowledgments}

We are very grateful to Eddy Petit, Institut Européen des Membranes, Montpellier, for material support and Dr. Stephen Jackson and Pr. Alan Dobson, Environmental Research Institute, Cork, for the fruitful discussions on the microbiological part. We also would like to thank ANR and FEDER for financial supports.

\section{References}

[1] C. Grison, N. Barthes, C. Finance, R.E. Duval, Bioorg. Chem. 38 (2010) 218-223.

[2] T. Conway, FEMS Microbiol. Rev. (1992) 1-27.

[3] J.-P. Pellmont, Bactéries et Environ. (1993). 
[4] C. Vidal, C. Chantreuil, O. Berge, L. Maure, J. Escarre, G. Bena, B. Brunel, J.-C. Cleyet-Marel, Int. J. Syst. Evol. Microbiol. 59 (2009) 850-855.

[5] C.M. Grison, S. Jackson, S. Merlot, A. Dobson, C. Grison, Int. J. Syst. Evol. Microbiol. (2013) (Submitted for publication).

[6] G. Losfeld, P.V. de La Blache, V. Escande, C. Grison, Green Chem. Lett. Rev. 5 (2012) 451-456.

[7] M. Chavarría, P.I. Nikel, D. Pérez-Pantoja, V. de Lorenzo, Environ. Microbiol. 15 (2013) 1772-1785.

[8] R. Plantier-Royon, D. Anker, J. Robert-Baudouy, J. Carbohyd. Chem. (1991) 239249.

[9] R. Ramage, A.M. MacLeod, G.W. Rose, Tetrahedron 47 (1991) 5625-5636.

[10] P. Coutrot, C. Grison, M. Tabyaoui, Tetrahedron Lett. 34 (1993) 589-592.

[11] P. Coutrot, S. Dumarcay, C. Finance, M. Tabyaoui, B. Tabyaoui, C. Grison, Bioorg. Med. Chem. Lett. 9 (1999) 949-952.

[12] P. Kampfer, Int. J. Syst. Evol. Microbiol. 53 (2003) 893-896.

[13] S.F. Altschul, W. Gish, W. Miller, E.W. Myers, D.J. Lipman, J. Mol. Biol. 215 (1990) 403-410.

[14] D.A. Evans, V.J. Cee, S.J. Siska, J. Am. Chem. Soc. 128 (2006) 9433-9441.
[15] P. Coutrot, C. Grison, M. Tabyaoui, S. Czemecki, J.M. Valery, J. Chem. Soc. Chem. Comm. (1988) 1515-1516.

[16] P.G. McDougal, J.G. Rico, Y.I. Oh, B.D. Condon, J. Org. Chem. 51 (1986) 3388 3390.

[17] J. Taunton, J.L. Collins, S.L. Schreiber, J. Am. Chem. Soc. 118 (1996) 10412 10422.

[18] C. Grison, S. Petek, P. Coutrot, Tetrahedron 61 (2005) 7193-7200.

[19] P.-H. Liang, J. Lewis, K.S. Anderson, A. Kohen, F.W. D’Souza, Y. Benenson, T. Baasov, Biochemistry 37 (1998) 16390-16399.

[20] Po-Huang Liang, A. Kohen, T. Baasov, K.S. Anderson, Bioorg. Med. Chem. Lett. 7 (1997) 2463-2468.

[21] V. Escande, L. Garoux, C. Grison, Y. Thillier, F. Debart, J.-J. Vasseur, C. Boulanger, C. Grison, Appl. Catal. B. 146 (2013) 1-298.

[22] G. Losfeld, V. Escande, T. Mathieu, C. Grison, Phytoextraction et biodégradation dynamisée: une approche interdisciplinaire inventive au service de l'environnement, Techniques de L'ingénieur Innovations En Environnement, base documentaire: TIB517DUO, 2013. 